\title{
4 White people fit for a new South Africa? State planning, policy and social response in the parastatal cities of the Vaal, 1940-1990 ${ }^{1}$
}

\author{
Bill Freund
}

\section{The poor white problem}

During the first half of the twentieth century, no issue exercised the white politicians of South Africa more than the problem of the "poor whites", remarkable if compared to the later stereotype that saw South African whites as almost all living in the lap of luxury. Johan Fourie traces written references to this apparent scourge back to $1886 .^{2} \mathrm{He}$ also characterises most explanations for white poverty to the difficulties of farming in South Africa where the AngloBoer War and then the Great Depression greatly accelerated crisis conditions and drove large numbers off the land. ${ }^{3}$ In a somewhat off-hand way however, Fourie lists a whole set of other causes and in fact these were probably also relevant often enough. Individual poverty cases will differ and may well have a dimension that is not due to macro-economic trends. ${ }^{4}$ I have argued years ago that both poverty and that "poor whites" are categories that can be defined in different ways depending on the historical context; they are not really scientific terms of any sort. ${ }^{5}$ The poor white problem was taken up as a political issue and with great enthusiasm by politicians and, for the National Party, as Lindie Koorts's recent biography of Malan reminds us, like almost no other over decades. $^{6}$ As such, economists are unable entirely to capture how the issue was understood and what really lay behind it.

The deepest connection lay in the link to racial thinking about the nature of South African society. ${ }^{7}$ Jeremy Seekings cited some years back a typical parliamentary response of the past:

The political imperative was explained by an NP MP, Dr. Stals, who had just won his seat from the South African Party. The "poor white" problem, he said: is a question which not only concerns the poor; it affects the whole white civilisation of this country. It confronts us with the question whether we, the descendents [sic] of the staunch old pioneers, will maintain their civilisation and hand it over to our children... It may be asked whether there is poverty only in South Africa and whether other countries do not suffer from the same thing. There are poor people everywhere, but the circumstances in South Africa are unique. ... In this country, there is 
a small number of whites against the natives, a few civilised people against uncivilised hordes, and for that reason it is so important that not a single white person should be allowed to go under. . . There is no greater problem than this, because the existence of the European civilisation in this country hinges on it. ${ }^{8}$

There was a more prosaic reason as well. The majority of the poor whites were potential voters and they were largely Afrikaans speakers. As Hendrik Verwoerd addressing the 1934 Afrikaner Volkskongres in the role of South Africa's first professional sociologist pointed out: 'Insover ' $n$ baie groot deel Afrikaanssprekend is, moes ons skat dat ongeveer een kwart van ons Afrikaanssprekende bevolking blanke armes is'. ${ }^{9}$ Thus the poor white question was directly political but also a cudgel for Afrikaner nationalists to take up as political competitors. Verwoerd even insisted that for the entire population, keeping whites up to reasonable civilised level was critical for the future of the country. In effect, one had to hold up the banner for what was referred to as "civilised labour". ${ }^{10}$

So how was this problem to be resolved? Thanks to the writing of Jeremy Seekings, we have a recent window on debates which marked the inter-war years in this connection. Seekings has convincingly shown that the US sponsored Carnegie Commission, meeting after 1931, was not on closer examination a turning point here as has been imagined. ${ }^{11}$ With a psychologist on its key research team and a big representation from the Dutch Reformed Church, the Commission was actually relatively hostile to the role of the state in alleviating poverty. Indeed Seekings argues that the Commission saw the poor white problem as fundamentally psychological. ${ }^{12}$ From this point of view, there were continual murmurings about the dangers of dependence, of the poor failing to meet their obligation as self-reliant Calvinists and the poisonous effect of a dole from the state. Poverty had to be linked to the troubles and weaknesses of particular individuals. This can probably also be linked to a rejection of urban life as the bright future of white South Africans. Back to the land was the sound movement. The Church (but the state as well) sponsored new agricultural settlements, for instance on the Orange River. The old view had been to leave the problems of poverty and destitution to family and church. The question of secularisation - and the resentment of the Church at being sidestepped - was an important one.

Yet Seekings argues that during the 1920s the Pact government particularly did intervene, and fairly effectively, in fighting poverty amongst white, and to a lesser extent, Coloured people (some of whom had the vote). Indeed General Hertzog liked to think that he had brought the poor white issue to a close, rather prematurely, as prime minister. Seekings goes further in taking the emphasis away from the shadowy poor white paradigm and the moralism with which it was suffused towards specific material reform in the direction of training social workers and offering material aid to dependent children and oldsters. A hallmark here was the establishment of a non-contributory old age pension scheme which took effect from the start of 1929. Another was the 1937 
Children's Act. In general, he argues that white South Africans did benefit from what was for the time a considerable start to a welfare state. Interestingly, this focus on state intervention was strongly promoted in a particular form by Verwoerd. He was particularly interested in the systematic training and diffusion of social workers, a new profession in South Africa in which he had himself been trained in the USA, who could direct the upliftment of the poor in the right way. In introducing the question of state intervention, he even referred to the potential nationalisation of the mining industry which towered over the South African business horizon.

The 1922 strike had been fought over the role of whites in the gold mines and it was a struggle which a state, determined to back the mining industry, won. ${ }^{13}$ There continued to be white workers on the gold mines but they were essentially supervisors of labour and tools of management, or genuinely skilled labour.They formed a very small percentage of the total labour force albeit that they won a much larger proportion of total take-home pay. The National Party largely, if begrudgingly, accepted this situation, but what about state employment and what about secondary industry? Well before Carnegie, a major factor as well was the willingness of the state to take on white and Coloured workers, at the expense often of Africans, in state employment. The chief exhibit for the interwar years was the railway system, ${ }^{14}$ but there were some others as well. When Parliament approved the creation of a state Iron and Steel Corporation in 1928, it was understood that it would be a resort for white workers to the greatest extent possible.

To go back for a moment to Verwoerd, he was far from the only force who thought about poverty as a sociological, not merely or even primarily, an economic construct. Parnell points us already in 1992 to the idea that proper state-initiated and supervised housing were thought also to play a civilising role in a civilising community and the Slums Act of 1934 cleared the way to the erection of what were seen as decent housing schemes to replace life in squalid pondokkies. ${ }^{15}$ Fourie also points to a feature which perhaps is the most under-researched: the role of education. ${ }^{16}$ This too can be a source of ideological intervention where workers' children are instructed in a way of behaviour and orientation and he mentions the growing educational levels of Afrikaans medium teachers during the inter-war years. However there is also the question of technical education aimed at jobs-orientated skills acquisition. This too took off in South Africa. On the whole, secular state intervention won the day in terms of the arguments for combatting white poverty. However other dimensions remain part of the picture and the assault against social ills has many prongs.

\section{Parastatal employment}

Here there was an opportunity to create entirely new settlements with no need to destroy slums and a large build-up of urban people where there had previously been none. In taking this on, there seem to be two central themes. The 
most direct is the provision of large numbers of jobs restricted to whites. The connection here to poverty alleviation was highly significant. The second, to be taken up later, is the subtler connection between what was considered advanced town planning at the time and an attempt to turn feckless white workers into what was called civilised labour. There is no automatic link between planned housing, whether or not state-owned, and racial or any other particular exclusion. This depends on the context of the society. It is true that any large-scale development built "to scale", however necessary and useful, will not please all inhabitants. This chapter seeks to explore the link that South African society held out to planning, not to condemn all planning.

There was once a very strong tendency on the part of liberal scholars and historians to contrast modern English ways of confronting social problems and organising society with the backward Boers progressing at an ox-wagon pace. Indeed segregation and apartheid were conveniently collapsed into this kind of perspective. As Seekings states, ${ }^{17}$ the range of state interventions already in place before the Carnegie Commission were themselves a deliberate thrust towards modernity married to "scientific" ideas about race and segregation, significantly promoted by Afrikaners. This is the way Steve Sparks has written about Sasol and Sasolburg, and Alan Mabin on urban planning generally, and I have tried to do the same in forthcoming work on developmentalism in South Africa. ${ }^{18}$ This is not to dismiss modernity as a racist plot but rather to understand it as an outlook that could take many forms and embrace racial division with white domination as common sense. This was true both before and after the fateful election of 1948 when the Purified Nationalists returned to power using apartheid as a slogan.

The creation and development of the parastatals had a huge impact on the economy of an increasingly prosperous South Africa, not only in the promotion of these very large firms with requisite infrastructure but in the general benefits for the expansion of heavy industry, notably in metals and chemicals. This chapter wishes to supply some evidence for this in the continuing national development after 1940, especially with reference to the entirely new towns of Vanderbijlpark and Sasolburg, created to serve the new state-initiated parastatals of ISCOR and Sasol respectively. During the 1940s and 1950s, African colonies were the site of numerous development efforts by the state which often went ludicrously or tragically wrong, but not all of the planning of that era failed to produce the desired effects. For all their social and environmental aspects which could be condemned, the key state-created industrial operations, ISCOR (steel) and Sasol (coal into oil), were in their own terms extremely successful. The London-linked money associated with the gold mines was very hostile to the creation of ISCOR. However, in time, Anglo American, the biggest private firm in South Africa, itself got into steel manufacturing on a big scale. South Africa had been Britain's largest customer for steel; this ended in the decade after World War II. For a generation, it was a great economic success story. ISCOR's privatised successor, Mittal, succeeded in selling large amounts of steel to China in more recent years moreover. Sasol today is South Africa's 
Table 4.1 Employment at Iscor by race ${ }^{19}$

\begin{tabular}{lrc}
\hline & Whites & Others (Natives, 1934) \\
\hline 1934 & 2,000 & 1,500 \\
1954 & 9,000 & 11,500 \\
1972 & 18,700 & 17,800 \\
\hline
\end{tabular}

biggest source of tax revenue and its massive new operations in the USA may well make it a major international player in the chemicals industry. These are anything but economic failures and at peak they employed very large labour forces. ${ }^{20}$

Yet already in the 1930s when ISCOR opened up its Pretoria plant, it quickly became fairly obvious that the initial idea of an all-white workforce was a fantasy. ${ }^{21}$ This was never going to be a viable case. However, it was a remarkable feature that the proportion of white workers was high, that it remained high right up to 1989 when ISCOR was privatised, and that hiring was policed in such a way that black workers were barred from all but the most primitive kinds of skill acquisition often described as "semi-skilled". ${ }^{22}$ Large numbers of whites were very well paid compared to blacks in the same factories. Thus in ISCOR in mid-1954, 9,000 whites earned $£ 50$ million, while 11,500 "Natives" earned f13 million. ${ }^{23}$

These proportions were in contrast to the mines where whites usually formed roughly only 10 per cent of the workforce. Gold, of course, was South Africa's number one export and the gold mining companies' imperative to keep white worker numbers down - admittedly with a huge percentage of the total wage bill - was consequently tolerated. As for ISCOR, worker numbers reached a peak of $76,000^{24}$ (dropping to 60,700 in mid-1982 and 49,560 at the end of 1985). ${ }^{25}$

The creation of new ISCOR mills in Vanderbijlpark in 1940 and in Newcastle in 1972 both resulted in management being obliged to cope with the requirement of maintaining a very large white labour force while the conditions of employment were such as to mop up white unemployment and indeed, until the final years, the industry created a job surplus that was problematic to fill. This was not met by excessive wages initially. Many white workers making $f^{2-3}$ per month or less in the 1950s received subsidy payments from the Department of Social Welfare. These bottom wages improved but apprentices continued to be a special category at the bottom of the wage ladder.

There remained the idea that unskilled workers were necessary but not worth much to capital. In South African terms, therefore, the issue was consequently how to train and keep genuinely skilled workers who had to be white on the job. This was a constant struggle.

There were several responses. One, about which more could certainly be researched, was education and training. The parastatals themselves ran training facilities, which were very important in producing acceptable workers. ${ }^{26}$ 
ISCOR had an excellent rate of completion of training bursaries on schedule 65 per cent instead of the usual 20 per cent - and 45 per cent of its working artisans had been trained by the company as of the start of the 1970s. ${ }^{27}$ This did not mean of course that artisans and other trained workers necessarily stayed at ISCOR or other state corporations for their entire career. Other employers paid better. However, they still entered the overall labour pool from a much improved starting point. Vanderbijlpark particularly attracted a number of industrial employers using ISCOR metal and metal products.

The parastatals were an important reason why "poor whiteism" largely disappeared as a social and political question in South Africa. It was still significant when the first two Purified National Party politicians, Malan and Strijdom, held power up to 1958 , but actually very little changed in 1948. It is a mistake from this point of view to see a dramatic shift with the onset of apartheid if by that one means the 1948-90 years when the National Party held power and promoted this slogan to replace segregation before it gave way in turn to "separate development". Concern with poor whites as a national question tended to give way to the search for a largely Afrikaans management class, particularly in state agencies. With Verwoerd in power, the system started to change significantly taken as a whole since the regime became obsessed with finding a means of building separation of the races within a white-dominated regional structure. For black South Africans, forced removals and the attempt to disrupt black urban life, although the latter was never entirely successful, meant a big change after 1958. However, for whites, the rules which enshrined earlier practices remained much the same. The economic empowerment of whites in the early apartheid years was an apotheosis of earlier policy. ${ }^{28}$

There was a constant but growing labour shortage. ${ }^{29}$ Stuart Coupe showed that for the metal and engineering trades generally, the number of white workers monopolising skills hardly increased in the boom years. ${ }^{30}$ Moreover, white South African workers with real skills were potentially quite mobile and the retention rates in the small town plants for ISCOR at Vanderbijlpark and Newcastle, were not good. Pretoria, with its more diverse economy, was better placed in this regard. However, the ISCOR plant in Pretoria lacked the space for expansion and met with increasing awareness of pollution problems, so it came to hold only a small share of operations.

A second answer lay in recruiting skilled workers in Europe, a policy that did not end for ISCOR until the last gasp of prosperity at the start of the 1980s. ${ }^{31}$ To take the example of ISCOR, these workers came not only from

Table 4.2 Iscor turnover rates p.a. $1971^{32}$

\begin{tabular}{lc}
\hline "Non-whites" & $59 \%$ \\
Operatives & $56 \%$ \\
Short service & $100 \%+$ \\
Artisans & $31 \%$ \\
Engineers & $12 \%$ \\
\hline
\end{tabular}


Britain, but from Germany, Switzerland, Sweden, Norway, Italy and the Netherlands, and later Greece. Particularly desirable were bricklayers, electricians, fitters and turners. ${ }^{33}$ In key periods such workers got a free passage to South Africa and housing with rentals fixed at a maximum of 20 per cent of their income. Beyond that, they were eligible for a Home Ownership Scheme and were required to join a workers' club. Some 27 engineers, 381 production workers and 421 artisans were hired from overseas in 1975, a late banner year. Integrating these foreigners was defined as a major task for the social services and schools. This kind of worker was unlikely to evolve quickly into a diehard Afrikaner Nationalist but everything was done to turn him into a civilised South African worker. It is also true that he was unlikely to object strongly to the racial policies which underwrote his own good wages.

A third strategy was to look for space in the workforce where management could situate white women, Coloureds and Indians. Already in the 1970s, management began to experiment with hiring women for what would previously been male jobs. This shift was obviously considered far less explosive than one fiddling with the racial ceilings. ${ }^{34}$ In addition, the 1976 Annual Report announced that there were 979 women employed in production, mostly in Vanderbijlpark and Pretoria, and there were additionally many administrative workers. However, women were still not deemed acceptable as artisans. ${ }^{35}$ The facility in Newcastle, with its large black population nearby in parts of the Zulu "homeland" and the presence of an Indian community better-primed for skilled jobs after the 1960s, also offered management some relief. ${ }^{36}$ In the middle of the 1970s, however, the refusal to train or accept workers of colour, especially in Vanderbijlpark and Pretoria, remained salient. ${ }^{37}$ Newcastle was less of a problem in theory with its Indian minority, but in fact this major new expanding facility in a town that did not have much appeal to white workers had its own difficulties in the form of high turnover. All in all, however, conditions evolved in the 1940s and 1950s so that it was the "poor whites" who began to have the upper hand in bargaining, and were able to enforce racial boundaries through their trade union, and armed by more upskilling in a very favourable labour situation. ${ }^{38}$ The problem only became less acute as the industry itself fell into crisis due to an economic downturn and slackening demand for workers. Sasol was not very different and indeed Crompton suggests that in the 1980s, security considerations favoured continuing dependence on regime-friendly whites. ${ }^{39}$ The managing director of ISCOR in 1985 pointed out to his minister that all ISCOR personnel, including management, came under systematic police and security surveillance. ${ }^{40}$

During the 1950s, the national archival record reveals ongoing concern with the question of Afrikaner employment at the parastatals. However, this was primarily a concern affecting top management and it connected most with the thrust for promoting national development under the Afrikaner nationalist aegis. It affected lower levels of staff to a limited extent, especially given the real-life conditions of labour shortages. The most important figures in the history of the parastatals were in fact Afrikaners who had emerged under the aegis 
of J.C. Smuts's United Party, notably the brilliant scientist and organiser H.J. van der Bijl, H.J. van Eck of the Industrial Development Corporation and Etienne Rousseau, key figure in Sasol. Rousseau, smarting from such criticism, quoted a message from Van der Bijl in his prime in 1945: 'Through ISKOR and other undertakings, he was doing more for the economic insertion of the Afrikaans speaker than what we are doing in Federale Volksbeleggings'. ${ }^{41}$ In a speech in his honour in 1972, Rousseau called Van der Bijl a "kampvegter" [champion] in the struggle to advance the Afrikaner. ${ }^{42}$

Despite the large numbers of whites, of course the workplace also employed a large black workforce, mainly consisting of contract workers staying in hostels and inured to harsh conditions from previous employment on the mines. The differentiation between black and white was extreme and enforced in the crudest of ways. Black overseers at ISCOR came equipped with sjamboks; white security guards and supervisors carried guns. The regime was particularly stark for hostel dwellers who had to wear special bracelets different from the house residents outside the hostel perimeter and could be confined to a detention room provided in the hostel. Hostel dwellers were largely recruited from rural sites in the Homelands, often with the assistance of chiefs, although ISCOR employees went out on recruitment drives. There was also humiliation from the naked medical examinations and the corporal punishment sometimes administered, as it was in the mines. The paternalist regime of Sasol and ISCOR and the industrial hegemony that underpinned all the early planning, based as it was on extreme inequality, was acceptable more from constraint than accord.

Furthermore, there was little or no mobility for blacks, unlike for whites. In 1967, ISCOR, which dominated the economy of Vanderbijlpark, opened up a training facility for black workers. The training consisted of a) an induction course, b) instruction in the bastard work language of Fanakalo, c) pre-school education, d) safety instructions, e) training of instructors and f) training of operators. That was it. Workers themselves remember training as being only to a limited extent about performing tasks and focussing mostly on the need to work hard and obey all whites. Fanakalo was in fact not extensively used on this account. Instead, workers were obliged to understand Afrikaans, which they resented acutely. Accident risk was discussed but in practice accidents were always defined as the fault of the worker. The compound dwellers especially were trained to see the world with racialised lenses but without of course the inherent racial assumptions of those responsible for the system. At least one popular work song summed it up: Qubula zasha, Abalungu ngodem (Lift up, damn the whites). Victor Munnik recorded the views of veteran ISCOR workers recently: 'Blacks were like tools. Where there was hard work, blacks were always taken. . . We were the first people to be the machines of ISCOR. We were the people who were doing the work of the machines of today'. ${ }^{43}$ Whites in stark contrast formed part of a Vaal Command and Sasolburg notably was the one constituency won by the far-right Herstigte Nasionale Party in a 1985 byelection. The racialised set-up in this extreme form was a major consequence of 
the "solution" to a national problem of policy confined largely to one minority racial group.

\section{Planning for race, class and family}

The core towns built for whites lay at the apex of the planning exercises. These are therefore classic suburban towns built according to plans in which particular areas reflected closely the cost and appropriate status in the parastatal world that went with positions at work, even though an increasing number of residents worked for firms other than the parastatals, albeit with parallel hierarchies. Alan Mabin has pointed out that the greatest common view of the time amongst the rising stars of urban planning was their hatred for messy, unsightly slums, their dislike of laissez-faire in urban development and their faith in what planning could do. He asks this question: 'Does this urge to control disorder and create separations characterise all modern planning?' These planning exercises were a 'marriage of modernity and racism' ${ }^{44}$

The assumption here is that the common view was applicable to most situations globally at a time when planning was gospel. However, it is important to note that the marriage to which Mabin refers was not necessarily the case universally. Thus a fascinating study of New York public housing at this time characterises its reforming proponents (often Communist Party members) as specifically intending to construct public housing in Manhattan to break down racial separation on the edge of Harlem. ${ }^{45}$ The construction of numerous housing projects at this time in some of the most affluent neighbourhoods of London where land had been cleared by wartime bombing was also in a different vein. Slum clearance also, of course, is not a despicable goal. This chapter takes the point of view that it is important to link the planning paradigm with particular South African norms and mores, not to denounce all planning or all modernity while understanding limitations and the consciousness around these trajectories.

Vanderbijlpark was laid out in 1941 on 25,000 acres purchased by the Iron and Steel Corporation of South Africa, including five miles of Vaal River frontage amounting to 40 square miles in all. For H.J. van der Bijl, who was then directing the South African economic war effort, Vanderbijlpark was a prize project that encapsulated his sense of the good life:

I visualised a town with people living in surroundings and under conditions which will be conducive to a healthy, happy and productive life. For this reason I was determined to make ample provision for parks, playing grounds, health clinics, hospitals and schools. A town, like a flower or a tree, should at each stage of its growth possess symmetry and completeness and the effect of growth should never be to destroy that unity but to give it greater purpose, not to mar that symmetry, which at all stages makes it a comprehensive whole. ${ }^{46}$ 
The 'roads [were] named after postal districts or scientists, engineers, musicians, medical men and the like' to give the town an elevated character. ${ }^{47}$ Van der Bijl had a fine house built on Beethoven Street. Great emphasis was placed on tree planting. While the town was to have a business centre with some apartment buildings, the dominant mode was suburban with an emphasis on green space and recreation and supposed isolation from industries, which were themselves to be relatively clean. The wealthiest neighbourhood around Beethoven Street still passes today, like the wealthier Northern suburbs of Johannesburg, as an urban forest.

The Vanderbijl Park Estate Company was created to produce houses on a mass scale efficiently and quickly. The goal of a new house finished every day was often realised. All of this was well developed before planning for the "Natives" even began - except on blueprint. Class differences in the white population were defining in terms of space. Particular blocks were all of a muchness in terms of size and amenity. The oldest modest parts of white Vanderbijlpark had no garages, although this changed in the 1950s. In Sasolburg, all purchased houses originally had garages but in an early phase, others were rented with only carports. In response to an indignant resident who felt demeaned by this, Minister of Economic Affairs Nico Diederichs felt obliged to respond that this was a gesture intended to benefit those who would struggle to pay higher rentals. $^{48}$

The town designer of Vanderbijlpark was Roy Kantorowich, a student of Carl Feiss at Columbia University, known for his enmity to the grand urban renewal plans of Robert Moses in New York City. Kantorowich was also implicated in the construction of the much-excoriated corporate/administrative high-rises on the reclaimed Cape Town Foreshore. Vanderbijlpark and the Foreshore evoked the two ideal forms in modernist thinking in architecture at the time: the green belt suburb with curving streets and easy avoidance of the growing menace of automotive traffic and the imposing dense high-rise for the city centre. It could be said that Kantorowich was one of a number of South African architects and planners eager to bring these ideas from the metropolitan high culture to South Africa: his greatest pride with regard to Vanderbijlpark was its contour road plan. ${ }^{49}$

Sasolburg, just south of the Vaal and inside the Orange Free State, proclaimed a white urban area in 1955, grew very rapidly until the economic crisis of the 1970s manifested itself. As with Vanderbijlpark, the plans, over which the architect-planners for a long time continued to hold control, saw Sasolburg in relative isolation, a world unto itself which was not really integrated into the farming and mining environment around the valley of the Vaal. Here, with the planning situated in the early apartheid period, streets were typically named for Afrikaners, or at least South African political figures and national heroes. Sasolburg was established under the direction of Max Kirchhofer, a Swiss immigrant who believed strongly in the green belt and was profoundly concerned with the issue of school location. He too believed that 'a town is an entity, a whole 
living organism' and that planners needed to focus on the 'self-contained residential precinct', a model easily adaptable to racial segregation. ${ }^{50}$

For Kirchhofer, as with Edwin Mallows, the British-born 'doyen of South African planning' at the University of the Witwatersrand, who worked closely with him on the site, the question of separation of automobile traffic from pedestrian usage was perhaps his biggest concern. The chief menace facing the South African town was 'the nerve-racking and dangerous intermixing of pedestrians and motor cars'. ${ }^{51}$ The cornerstone of a neighbourhood was to be the primary school to which resident children could walk safely without crossing busy roads. ${ }^{52}$ The principal environmental idea in both cities, apart from functional separation, was the massive planting of trees, including in the black locations. This forest effect is noticeable to the present day when it incurs worry as shrubbery hides criminals and pathways become littered or unkempt.

Kirchhofer was inspired by the New Towns being constructed in post-war Britain on top of ideas that came from his native Switzerland about urban citizenship and urban tidiness. He would have identified himself as a liberal and liked to consider that potentially as much thought was given to black housing in Sasolburg as to white. ${ }^{53}$ In the factors that he took as professionally important, the black population had the same needs as the white and these were accordingly accommodated, or so he was convinced.Yet "organisms" could display gross inequalities and in Sasolburg, they did. Moreover in Sasolburg, typical of many South African cities of the day, a curfew for Africans operated by decree after 9 PM. The Vanderbijl Park town clerk opined in 1952 that it is the Committee's policy to endeavour to keep the natives out of the European areas as far as possible. For this reason steps have been taken to provide shops, recreation and social centres and a clinic at Bopelong'. ${ }^{54}$ Not only did these small townships have little planned business districts, there was even a hope that they would develop craft centres and reach the ideal that blacks would rarely have to be spotted in the white town.

However, what is perhaps even more striking than the tiered layers of demarcation created by housing is the extent to which the white town in both cases was intended to civilise the paler skinned natives. White louts unused to urban living were to be made accustomed to a regime of suburban neatness and order and hopefully rendered suitable for further social and material mobility, while foreigners unused to the South African "way of life" had to be domesticated. Club membership for immigrant ISCOR employees was a requirement. It was hoped that the system of amenities, much of it sporting, would also have a socialising effect. In time, VESCO, the planning agency, actually introduced large African fauna to Vanderbijlpark (which abutted the Vaal) as a symbol of desirable appreciation of the national environment. ${ }^{55}$ Sasolburg was equipped with a botanical garden and a bird sanctuary. ${ }^{56}$ Those numerous men hired who were not married were placed in controlled situations - specially designed hostels with appropriate recreational facilities nearby. Residential areas were placed separately from business premises. Churches were located far from spots where 
men might take to drinking. Neat lawns were supposed to stay clear of rusting old cars and other working-class or farm boy appurtenances.

In a correspondence over what was termed "backyard development", the Swiss Kirchhofer considered that untidy backyards were a throwback to rural living that needed to be eliminated through strict regulation according to his big plan. They were due to the fact that

living in towns is a new experience for a large portion of the white population of this country. It is understandable that the backvelder when he moves into the closely knit urban pattern will bring with him a mode of life conditioned by the vast open spaces.... A certain amount of guidance would be helpful and strict application of the laws should do the rest. ${ }^{57}$

This, he argued, was better than the official idea of concentrating on hiding views of the backyards. For a long time in both towns, authorities attempted to enforce planning regulations that fitted the original plans of the architects approved by the state. It was claimed in 1949 by ISCOR that 'the Company will not permit any alterations or additions to the existing buildings, which will tend to destroy the character of the buildings in terms of the Establishment designed for use as a dwelling for a single family'. The Archives are replete with detailed correspondence about proposed alterations through the 1970s. However, this and other aspects of the model town order, was a never-ending struggle.

Reality was a bit more complex than the exhaustive planning exercise. Sasolburg was probably created with the desideratum that domestic workers should be forced to live in the location rather than 'accommodating them on the European premises' - something that proved impossible to enforce. Kirchhofer fended off any responsibility for this later. 'All squatting was to be prohibited' ${ }^{58}$ However, before permanent dwellings were available, where were the workers to stay? From the beginning, squatting was hard to control. ${ }^{59}$ The female domestic workers who were permitted to live on premises inevitably had male visitors and, more furtively, resident lovers or husbands whose residence promoted the availability of workers to the employer. It could not possibly be illegitimate for these women to go to church and worship God, but that required inevitably large black crowds walking through white Sasolburg, for instance, on a Sunday. Another anomaly in the system, critical in the phase where black labour was in heavy demand, was the apparent right of potential workers to spend the first 72 hours in a proclaimed white area without an endorsed pass while looking for work. Finally, there was the problem of legitimate workers for whom there was no legitimate space in the townships. A fascinating memorandum from 1958 points to the large presence in Sasolburg of men and children in servants' quarters; the domestic workers were successful in agitating to the end that there would be no work for the white household if these were expelled with nowhere to go. ${ }^{60}$ Such households were obviously tempted to wink at regulations vis-à-vis Sasol workers if they had a satisfactory arrangement with their employees. 


\section{Indocility}

Life in a regulated small industrial city was less attractive to a workforce than was imagined in the dreams of van der Bijl and the city planners. Workers had their own ideas about what they were doing with their lives ${ }^{61}$ It is not entirely by chance that the most famous Afrikaner anti-establishment rock and roller, Johannes Kerkorrel, came from a modest home in Sasolburg. Whites exhibited both a loyalty critical in some respects to the whole parastatal-governmental authority but they sought to carve out space that did not always fit what the authority desired or sometimes even opposed. Regimentation for whites bred rebelliousness.

Real life did not by any means entirely follow the dictates of civilised labour. Whites who did not like the controlling regime of the company towns also turned to the countryside where they could lead an unregulated or much less regulated existence. This also involved business possibilities, illegal or unregulated. On a little property, a man could keep a few cows and grow some maize as well as tinker at rusty machinery and fix cars. In time, many white families, for example, settled in what became known as Greater Steel Valley, close to the ISCOR factory, on some 600 smallholdings. ${ }^{62}$ This was originally defined as a waste disposal area but got settled anyway. Here ISCOR employees engaged in multi-tasked, multi-income lives on land that was disastrously polluted well outside the regulated world of the town.

The Verwoerdian system tried to put itself forward as apartheid, racial separation. It put itself forward as different from crude racial mastery by whites or, to take the familiar Afrikaans expression, baasskap. I would propose that workingclass whites generally enjoyed and profited from baasskap but were not necessarily taken with racial separation. Resident whites may have been keen on racism and racial laws, but they also sometimes profited from illegal activities and sponsored them themselves. Like the black residents, they often preferred to shop in the multi-use Vereeniging centre rather than the planned precincts of the new towns. ${ }^{63}$ As was generally true in the Vaal Triangle region, smallholdings housed not only white individuals and families but workers and other black residents in time-honoured fashion. In 1967, a survey by the Vanderbijlpark Council found 4,555 Africans in the surrounding area. ${ }^{64}$ This was also true south of the Vaal around Sasolburg, albeit less densely. ${ }^{65}$ Some were temporary ISCOR construction workers. Only 353 were farmworkers legally employed but the largest number were domestic workers, employees doing work other than agricultural work, and minors. In the official records, bureaucrats were plagued with complaints by white residents about supposedly illegal black activities and presence, although generally found to be more or less legal in fact.

The Vaal Triangle towns were very largely a black and white world. Only in Vereeniging were there established communities of Indian traders and workers and a small settled population of mixed race. Neither Indian nor Coloured people were officially welcome in Vanderbijlpark or Sasolburg. ${ }^{66}$ Sasolburg was in fact located south of the river in the Orange Free State, where Indian residence 
was illegal. The small Coloured presence in Vanderbijlpark (even smaller in Sasolburg) was a source of ongoing if low-key official anxiety, as there was no "group area" to house the handful employed there. ${ }^{67}$ Finally, an attempt was made to move all the Coloured people in the Triangle to Grasmere outsideVereeniging. ${ }^{6}{ }^{6}$ However, apart from the misery it caused, this was quite impractical and led to Coloured people living illegally on peri-urban properties or elsewhere. ${ }^{69}$

Moreover, for other transactions involving sex and other relations between men and women, marijuana, gambling opportunities or, above all, beer, there was a difficult to control world of peripheral peri-urban properties. In the Verwoerd era, trawling the peri-urban sea was an important but unending task for mariner policemen. ${ }^{70}$ Here it was possible to find ramshackle businesses of all sorts. Owners might be absent; in a few cases, they were themselves not white and here transgressions could occur. Thus, in 1954, officialdom discovered that a whole row of Indian-owned shops and houses could be found at the southern border of Vanderbijlpark on the property of a Coloured woman, Susan Wessels, married to an Indian man described as a general dealer named Kajee Omar. However, some of these shops appeared to be rented from white men in Vereeniging. This typical anomaly was shut down but would reappear in new guises. ${ }^{71}$ In 1961, state agents found once again the row of Indian shops on the south end of Bophelong, rented from white women in Vereeniging, this time full of white shoppers who preferred it to the carefully planned town centre. This zone included Chinese businesses that bore the traces of gambling for the day's horse races. ${ }^{72}$ From Zamdela, the Sasolburg township, while it was true that it was rather easy for black residents to walk to the Sasol entrance, the reality was one of littered, unsanitary and potentially even dangerous footpaths by the dozen. Moreover, Sasolburg had attracted African Explosives and Chemicals Industries and other employers, creating more complicated trajectories that could hardly be stopped. ${ }^{73}$ This irregularity had already irritated the planners twenty years earlier in Vanderbijlpark. ${ }^{74}$ These very conditions that had so horrified early city fathers in Johannesburg, in Vrededorp and Fordsburg early in the twentieth century, simply recreated themselves, albeit on terms rather more favourable to white workers.

An apocryphal bit of Sasolburg urban legend was the monthly encounter at the Sasol factory gate between husband and wife. The wife took the money required for household necessities immediately on payment and the husband then went off with his mates for a major weekend drinking bout, marking an incomplete if perhaps predictable social transition from the point of view of the planners. Whites occasionally exploded outside the confines of the company controls. In Vanderbijlpark, a resident who worked for Metal Box recalled that in the early days, 'there was one pub and it saw fights every night' ${ }^{75}$ This in turn meant that white civil society required not merely the intervention of the churches but of welfare and charitable organisations with a mission to intervene in acute social problems. Far from sounding the knell on religious and aligned interventions, these company towns offered extensive new possibilities. The Red Cross, Noodhulpliga, Kindersorg, Family and Marriage Society of 
South Africa, the Cancer Union, Kreupelsorg and the South African National Council for Alcoholism had no problem keeping busy on the Vaal. ${ }^{76}$

These activities could not be considered as resistance to ISCOR; indocility captures the reality better. ${ }^{77}$ It was only after the end of the apartheid government that residents felt empowered to engage in protest against the big employer, which apart from employing the majority, was also sometimes the provider of credit. ${ }^{78}$ Until apartheid broke, it was reported that ISCOR people tended 'to work for ISCOR for their whole lives and you step into a culture of how people do things'. ${ }^{79}$ Moreover, even the white smallholders were bound to ISCOR by the accepted dictates of security in a beleaguered white South Africa; many were members of an ISCOR Command.

\section{Conclusion}

The new towns of the Vaal went hand in hand with massive new job opportunities for the poor whites of South Africa. Whites had many arrows in their quiver to rule out African competition for their jobs even though considerable migrant labour was necessarily brought to ISCOR and Sasol to meet part of the needs of management. Indeed by the end of the 1950s, the situation in the parastatals was best characterised in terms of labour shortage. There were extensive opportunities for whites to acquire skills that made them increasingly independent of state patronage with time. It is less clear if what we might term high modernist cultural forms, notably in the planning and organisation of these towns, were very successful in diffusing notions of suburban respectability. The former poor whites had their own ideas about how they wanted to organise their lives under increasingly favourable conditions.

Fourie has made a very welcome and important intervention in proposing that current analyses of poor whites ought to consider the situation of poor black South Africans today, even if his insistence on the efficacy of home ownership as a solution may be less than convincing. ${ }^{80}$ Nothing is more central than the struggle against unemployment and overly precarious forms of labour even though, as a recent collection reminds us, this can only be a long and complex set of interventions that will also require far more co-ordination. ${ }^{81}$ The role of skill endowment and of education cannot be overestimated here. This enables individuals to find new possibilities and new situations even if a particular employer is no longer able to provide work. Parnell's point about the centrality of housing, carried through in our assessment of the planning involved in the Vaal Triangle towns, is not without a strong echo in the social housing policies carried through by the African National Congress since 1994. Moreover, there is probably an equivalent, even under the most positive conditions, of discomfort and rebelliousness as the beneficiaries of development programmes take up directions that authorities do not expect. It is important to see historical development as the result not only of state legislation and decrees, not only as the product of the plans of private and public sector bureaucrats, but that the poor, whether or not white, also have agency. The poor white question entangled 
moral and racial ideology together with practical economic questions. This analysis hopefully takes the positive benefits of modernisation in tow without missing the negative side, which abstracted from economic considerations to insist on a paternalist vision that was impossible to be enacted without struggle and indocile reactions.

\section{Notes}

1 I have to thank for their personal guidance on this material in particular Steve Sparks, Alan Mabin,Victor Munnik and Mark Oranje. This work draws heavily upon material from within B. Freund, Twentieth Century South Africa: A Developmental History, 2019 (C) published by Cambridge University Press, reproduced with permission.

2 Fourie, 'South African Poor White Problem'.

3 See also Seekings, 'The Carnegie Commission', 518.

4 For a sordid tale that dramatically highlights the interrelationships of small town and rural poor whites, landowners and black farmworkers, economic, criminal and social behaviour at the turn of the twentieth century, see Krikler, 'South African Murder'. The plot concerns the alleged murder of a white tenant by the landowner who is having an affair with the tenant's wife in the Volksrust area of the Transvaal.

5 Freund, 'Introduction: The Poor Whites', xiii-xxiii.

6 Koorts, D.F. Malan.

7 Dubow, Scientific Racism.

8 Seekings, 'Origins of South Africa's Welfare State'.

9 'Insofar as a very large part [of the poor white population] is Afrikaans-speaking, we must estimate that perhaps one-quarter of our Afrikaans-speaking population are poor whites.' My translation. Hendrik Verwoerd in Joubert, Toe Witmense Arm Was, 54.

10 Seekings, 'Origins of South Africa's Welfare State', 9.

11 Seekings, 'The Carnegie Commission'.

12 Ibid., 520.

13 Davies, Capital, State and White Labour; Krikler, White Rising;Yudelman, Emergence of Modern South Africa.

14 Pirie, 'White Railway Labour'.

15 Parnell, 'Slums, Segregation and Poor Whites'.

16 Fourie, 'South African Poor White Problem'.

17 Seekings, 'The Carnegie Commission', 519.

18 Freund, Twentieth Century South Africa; Mabin, 'Legacies of Modernism', 560; Sparks, 'South Africa's Oil from Coal Project'.

19 NASA MES 232, H 4/12 pts 1/2; MPP 45, A3/10/9, part 1.

20 For more on this, see my volume with Cambridge University Press, Twentieth Century South Africa; A Developmental History. I am very grateful to CUP for allowing me to excerpt material from this manuscript in this paper.

21 Morris and Kaplan, 'Labour Policy in a State Corporation'; Davies, Kaplan, Morris and O'Meara, 'Class Struggles'.

22 Webster, Cast in a Racial Mould looks at the heavy metal sector of industry from the perspective of the labour process and the conjuncture of Taylorism and South African racial divisions. He paid attention to the general situation of black labour migrants as well as whites with recognised skills and did some research in the Vanderbijlpark firm of Vecor.

23 National Archives of South Africa (hereafter NASA) MES 232, H 4/12, pts. 1/2, Annual Report 1955.

24 NASA MPP 17, A3/1/6/4/4 part 1, Unconfirmed Board Minutes, ISCOR, 30 January 1985.

25 NASA MPP 17,A3/1/6/4/4, ISCOR Annual Report to Minister, 31 December 1985. 
26 NASA MPP 233 H/4 12 vol. 3, Memorandum from Admin. Director J. P. Coetzee to Minister of Economic Affairs O. Horwood, 10 September 1974.

27 NASA, MPP 23, A3/10/1 part 1, LCJ de Villiers, ISCOR Personnel Manager, Report on Manpower, May 1971.

28 For an extensive articulation of this, dividing the apartheid years into three periods, see Freund, Twentieth Century South Africa.

29 Schirmer, Sunday Times, 26 January 1969; NASA MES 244, H4/12/3 v.2, ISCOR Annual Report 1965.

30 Coupe, 'Divisions of Labour'.

31 NASA MPP 51, A3/10/9 Verslae en Notules, ISCOR Monthly Report, 30 September 1981.

32 NASA MPP 23, A3/10/1 part 1, LCJ de Villiers, Personnel Manager, Report on Manpower, May 1971.

33 NASA BTS no volume 8/19/5, Facts about employment with ISCOR in Vanderbijl Park cyclostyled, for prospective employees; Secretary of Domestic Affairs to Secretary, Foreign Affairs, 29 May 1951; AES 13, AM 7/7 part 1; Annual Report ISCOR 1963; Secretary, Ministry of Trade and Industry to Secretary, Ministry of Foreign Affairs, 9 September 1963.

34 NASA MPP 23, A3/10/1 part 1, LCJ de Villiers, Personnel Manager, ISCOR, Report on Manpower, May 1971.

35 NASA MPP 45, 3/10/9 part 1, ISCOR Annual Report 1976.

36 Ibid.

37 NASA AFE 30, E4/12/3.

38 Webster, Cast in a Racial Mould.

39 Crompton, 'The South African Commodity Plastics Filiere', 157.

40 NASA MPP 17, A3/1/6/4/4 part 1, F P Kotze, Mg Director, ISCOR to D J de Villiers, Min of Trade and Industries, 1 April 1985, extremely secret.

41 NASA MES 218, H 46/6 v. 1 and 46/7. My translation.

42 Engineers' Liaison Committee of Pretoria, Hendrik van der Bijl Lesings-Lectures 196372, Address by P.E. Rousseau 1972, 123.

43 Munnik, 'Discursive Power and Environmental Justice'.

44 Mabin, 'Legacies of Modernism', 560. Mabin has also shown that the model outlined below was prefigured in existing settlements from the time that industrial-level economic activity took off in Mabin, 'Origins of Residential Segregation in Kimberley'. In Kimberley however what were defined as slums needed to be destroyed.

45 Zipp, Manhattan Projects.

46 Sasol Papers, Cullen Library, University of the Witwatersrand (hereafter Sasol Papers), AG 2207, F21 P. Nell, An Historical Review of the Town of Vanderbijl Park for the Period 1941 to December 1951, Van Riebeeck Festival Committee, Vanderbijl Park, 3.

47 Ibid., 5.

48 NASA MES 218, H 46/6 v. 1 and 46/7, Diederichs to Mev. C. F. Cilliers, 28 July 1959.

49 Kantorowich, Interview with Alan Mabin, 1991.

50 For Kirchhofer's vision, see Kirchhofer, 'Sasolburg OFS'. See also Sasol Papers, AG 2207, B4, Notes on the Planning of Sasolburg, 1957.

51 Sasol Papers, AG 2207, B4, Max Kirchhofer to D.P. de Villiers, 3 August 1957. As occasionally appears in correspondence, Kirchhofer's largest anxiety insofar as the Plan was adhered to, was the inevitable proximity of white suburbia to a giant chemical plant. He believed that Sasolburg was too hemmed in and would be prey to the chemical plant's 'smoke and smell'. However, he also thought that tree planting would solve the problem. In fact he had far less space with which to work than did Kantorowich atVanderbijlpark.

52 Kirchhofer, 'Sasolburg OFS', 26.

53 Beavon records for Johannesburg also apparently benign plans to suit garden city cities both for Orlando before World War II and Dube afterwards in considering the origins 
of Soweto, Beavon, Johannesburg, 121-130. However, such plans were trimmed down dramatically in reality and the Vaal Triangle would also display this truncated planners' vision when it came to African inhabitants' neighbourhoods.

54 Sasol Papers, AG 2207, F21, Nell, Town of Vanderbijl Park, 15.

55 The game park near the river housed at peak four rhinoceroses, two lions, 57 springbok and 29 impala. However, the lions were overly confined and the rhinoceroses ate up the bush excessively. Most of the game died out. The goal remained 'quality outdoor recreation'. Sasol Papers, AG 2207, F30, Mallows, Louw and Hoffe, Vanderbijlpark Riverside: A Proposed Development Plan for the Vaal River Front, 1973

56 NASA GMO v. 1/ 7234, Max Kirchhofer, Guide Plan for Sasolburg, November 1975, Notes. In effect Max Kirchhofer was really concerned with the aesthetic and did not come to grips with the basic environmental issues. For early environmental issues that were surfacing in Sasolburg from 1960, see NA ARB 1226, 1042/11/952.

57 Sasol Papers, AG 2207, B4, Max Kirchhofer to D.P. de Villiers, 3 August 1957.

58 Sasol Papers, AG 2207, B1, Interview with Director, Native Labour, 23 July 1951.

59 NASA NTS 6134, 481/313N, P.E. Rousseau to Verwoerd, 26/8/52.

60 NASA BA9268, A15/1603. Regulations for Management of Bantu Residents, Sasolburg; WHS Sharp, Secretary-Treasurer, Village Administration of Sasolburg to Native Commissioner, Vereeniging, 15 January 1958.

61 For an interesting parallel, see Harrison and Zack, 'The Wrong Side of the Mining Belt?' Especially their comments on South Hills (Johannesburg) public housing. Here too the planners originally entitled their project Welfare City and were filled with good intentions aimed at civilising poor white residents.

62 See map, NA BAO 1561,A18/1709 pt. 1.

63 Prinsloo (ed), Yskor; Vanderbijlpark-Werke 1943-93, Unpublished ms. (Potchefstoom Universiteit vir Christelike Hoër Onderwys 1993).

64 NASA, BAO 8005, 164/1708, part 1, Head Commissioner, Bantu Affairs to Secretary, Bantu Affairs, 9/6/67.

65 NASA NTS 5846, 481/313/M, Memorandum, Secretary, Administration of Native Affairs, 4/4/57 with further letter 29/4/57 and record of meeting 27/3/58.

66 The 1960 census counted no Asians and 110 Coloured persons in Sasolburg, largely domestic workers. NASA ARG v. 163 VK 132/1/14, 1 Verwysings van Beplanningskomitee, verslae: Town Council of Vanderbijl Park, 1953 Memorandum on the Proclamation of Group Areas. NASA GMO v. 1/7234, Sosiografie.

67 NASA, NTS 7064, 404/322, P Nell, Town Clerk to Native Commissioner, Vereeniging, 18/3/56; BEP 506, G7/550 1 and 2, W H S Sharp, Secretary,Village Board of Management to Provincial Secretary, Bloemfontein, 8/8/60.

68 NASA, BAO 1561, A18/1709/pt. 1, JS Campbell, Ag. Town Clerk to Secretary, BAD, 6/7/ 1962.

69 NASA, BAO 1747, A19/1603 v. 1, W H Sharp, Town Clerk, Sasolburg to Secretary, Department of Planning, 22/5/69.

70 This official suggested setting up a Labour Tenants Control Board to this end. NASA, BAO 9575, B23/5/1603, CP Barnaard, official entrusted with the carrying out of Chapter 4 regulations to First Administrative Official, Squatter Management, 11/10/62.

71 NASA BEP 228, G7/170/7, Enclosure in P R Nell, Town Clerk, to Land Tenure Advisory Board, 24/5/54.

72 NASA, BEP 228, G7/170, Groepsgebiede te Vanderbijlpark, 2/10/62, Gemeenteskapreport.

73 Sasol Papers, AG 2207, K1, M. C. Tisdall, Manager, Production of Co-ordination and Despatch, to General Manager, SBD, Sasol, 16/7/76.

74 NASA NTS 7064, 404/322, P Nell, Town Clerk to Native Commissioner, Vereeniging, 25/3/54.

75 Prinsloo (ed), Yskor; Vanderbijlpark-Werke, 166. 
76 Ibid., 167.

77 My larger project concerns itself in some detail with the changing situation of black residents in these urban areas far from any so-called Homeland and without any urban tradition largely left out here.

78 Prinsloo (ed) 'Yskor'; Munnik, 'Discursive Power and Environmental Justice', 118.

79 Munnik, 'Discursive Power and Environmental Justice', 274.

80 Fourie, 'The South African Poor White Problem'.

81 Black, Towards Employment-Intensive Growth. 